\title{
Factors Effecting COVID-19 Vaccine Refusal and Hesitation After Initiation of National Vaccination Program in Turkey
}

\section{Türkiye'de Ulusal Așı Programının Bașlatılması Sonrası COVID-19 Așı Reddi ve Tereddütünü Etkileyen Faktörler}

\author{
Onur ÜNAL ${ }^{1}$ (IID), Gülin ÖZDAMAR ÜNAL ${ }^{2}$ (IDD), Süleyman Emre ÖZYÜREK ${ }^{3}$ (IID)
}

\footnotetext{
${ }^{1}$ Department of Infectious Diseases and Clinical Microbiology, Süleyman Demirel University Faculty of Medicine, Isparta, Turkey

${ }^{2}$ Department of Psychiatry, Süleyman Demirel University Faculty of Medicine, Isparta, Turkey

${ }^{3}$ Division of Child and Adolescent Psychiatry, Süleyman Demirel University Faculty of Medicine, Isparta, Turkey
}

Cite this article as: Ünal O, Özdamar Ünal G, Özyürek SE. Factors effecting COVID-19 vaccine refusal and hesitation after initiation of national vaccination program in Turkey. FLORA 2021;26(4):610-9.

\begin{abstract}
Introduction: Safe and effective prophylactic vaccines are needed to control rapidly advancing COVID-19, which has devastating medical, economic, and social consequences. It is believed that one of the most critical obstacles to vaccination activities is negative attitudes towards vaccines. This study aimed to identify factors associated with COVID-19 vaccine rejection and hesitation after initiation of the national vaccination program.

Materials and Methods: The study was conducted using an online questionnaire. Participants' socio-demographic and clinical data and COVID-19 outbreak experiences, attitudes towards the vaccine of COVID-19 were collected through a specially designed structured questionnaire. The participants were also asked to complete Death Anxiety Scale (DAS) and Health Anxiety Scale (HAS). Multiple logistic regression analyses were performed to reveal the factors predicting vaccine hesitancy and rejection.

Results: A total of 1,546 completed responses were received. Vaccine hesitation and refusal rates were $8.9 \%$ and $9 \%$, respectively. Older age, high education level and lower concern on the vaccine was observed in participants that accepted vaccination compared to patients who refused and hesitated vaccination. High education levels and healthcare workers had decreased risk of vaccine hesitancy. High Death Anxiety Score and being a healthcare worker had decreased risk for vaccine refusal. Concern about the vaccines was the most important risk factor for vaccine hesitancy and refusal.

Conclusion: Our study suggested that vaccine hesitancy was related to lower education level, and negative concern about the vaccine. Vaccine refusal was related to history of COVID-19 infection, negative concern on the vaccine, non-healthcare occupation, and higher level of death anxiety scale.
\end{abstract}

Key Words: COVID-19; Death anxiety; Health anxiety; Vaccine hesitation; Vaccine refusal 


\title{
Öz
}

\section{Türkiye'de Ulusal Așı Programının Bașlatılması Sonrası COVID-19 Așı Reddi ve Tereddütünü Etkileyen Faktörler}

\author{
Onur ÜNAL', Gülin ÖZDAMAR ÜNAL², Süleyman Emre ÖZYÜREK ${ }^{3}$
}

\footnotetext{
' Süleyman Demirel Üniversitesi Tıp Fakültesi, İnfeksiyon Hastalıkları ve Klinik Mikrobiyoloji Anabilim Dalı, Isparta, Türkiye

2 Süleyman Demirel Üniversitesi Tıp Fakültesi, Psikiyatri Anabilim Dalı, Isparta, Türkiye

3 Süleyman Demirel Üniversitesi Tıp Fakültesi, Çocuk ve Adolesan Psikiyatrisi Bilim Dalı, Isparta, Türkiye
}

\begin{abstract}
Giriș: Olumsuz tıbbi, ekonomik ve sosyal sonuçları olan hızla ilerleyen COVID-19 pandemisini kontrol etmek için güvenli ve etkili profilaktik aşılara ihtiyaç vardır. Aşı faaliyetlerinin önündeki en kritik engellerden birinin aşılara yönelik olumsuz tutumlar olduğu düşünülmektedir. Bu çalışma, ulusal aşı programının başlatılmasından sonra COVID-19 aşı reddi ve tereddüt ile ilişkili faktörleri belirlemeyi amaçlamaktadır.

Materyal ve Metod: Çalışma, çevrimiçi bir anket kullanılarak yürütüldü. Katılımcıların sosyo-demografik, klinik verileri, COVID-19 pandemi deneyimleri ve COVID-19 aşısına yönelik tutumları özel olarak tasarlanmış yapılandırılmış bir anket aracılığıyla toplandı. Katılımıılardan ayrıca Ölüm Kaygııı Ölçeği (DAS) ve Sağlık Kaygııı Ölçeği'ni (HAS) doldurmaları istendi. Aşı tereddüt ve reddini öngören faktörleri ortaya koymak amacıyla lojistik regresyon analizleri yapıldı.
\end{abstract}

Bulgular: Toplam 1.546 tamamlanmış yanıt alındı. Aşı tereddüt ve red oranları sırasıyla \%8.9 ve \%9 idi. Aşıyı kabul edenlerin, aşıyı reddeden ve tereddüt edenlere göre yaş ve eğitim düzeylerinin yüksek ve aşıya yönelik endişelerinin daha az olduğu görüldü. Eğitim seviyesi yüksek olanlarda ve sağlık çalışanlarında aşı tereddütü daha düşüktü. Yüksek Ölüm Kaygısı Skoru ve sağlık çalışanı olmak aşı reddi riskini azalttı. Aşılarla ilgili endişe, aşı tereddütü ve reddi için en önemli risk faktörüydü.

Sonuç: Çalışmamız, aşı tereddütünün düşük eğitim düzeyi ve aşılara yönelik endişe ile ilişkili olduğunu düşündürmektedir. Aşı reddi, COVID19 infeksiyonu öyküsü, aşılara yönelik endişe, yüksek düzey ölüm kaygısına sahip olma ve sağlık çalışanı olmama durumu ile ilişkiliydi.

Anahtar Kelimeler: COVID-19; Ölüm kaygısı; Sağıık kaygısı; Aşı tereddütü; Aşı reddi

\section{INTRODUCTION}

Since the announcement of the pandemic by the World Health Organization (WHO) on 11 March 2020, until today (29 June 2021), there have been 181.176.715 confirmed cases worldwide and more than 3.930.496 deaths due to COVID-19 infection ${ }^{[1]}$. The rapid spread of the virus, the observation of various clinical courses associated with the virus, leads to many deaths, and the absence of specific treatment raises many questions to be clarified ${ }^{[2]}$. Despite strict measures to take the pandemic under control, COVID-19 continues to threaten the world.

In Turkey, the Ministry of Health has identified priority groups to be vaccinated, considering the risks of exposure, severe disease, and transmission of COVID-19 disease. An inactivated vaccine has been administered to these groups in January 2021. Up to June 2021, 34.118.163 people received the first dose, and 15.020.130 people received the second vaccine dose $e^{[3]}$.
It is emphasized that perceptions of disease risk, concerns about the vaccine's reliability and effectiveness, general attitudes towards vaccines, cultural differences, and psychosocial variables may play a role in the hesitancy of a new vaccine $^{[4]}$. The emerging mental reactions associated with the pandemic are observed in different characteristics and severity. Some people experience high levels of health and death anxiety, while some tend to ignore the severity of the epidemic by experiencing lower anxiety levels ${ }^{[5]}$. We believe that these psychological responses may have an impact on COVID-19 vaccination.

We developed a survey to explore the potential factors that determine attitudes towards COVID-19 vaccines. This survey included socio-demographic data that we believed to be important for attitudes towards the COVID-19 vaccine, personal experiences with COVID-19, and questions to identify thoughts about COVID-19 infection and the vaccine. 
We aimed to detect factors effecting COVID-19 vaccination refusal and hesitancy in Turkey.

\section{MATERIALS and METHODS}

\section{Study Design and Participants}

In this descriptive study designed to protect against the risk of SARS-CoV-2 transmission and reach a broader population, data were collected from 21 to 26 February 2021 using Google Forms web software. The link to the study was delivered to the participants via the most commonly used online messaging platforms (WhatsApp, Twitter, Facebook, E-mail) in Turkey. Inclusion criteria: 1. Age 18 and older. 2. The residents in Turkey. The participants who followed the link were informed about the study in writing. Participants were not compensated for participation. This research was approved by Süleyman Demirel University Faculty of Medicine Clinical Research Ethics Committee (Date: 08/01/2021, Number: 15).

\section{Measures}

Participants' socio-demographic and clinical data and their experiences with the COVID-19 pandemic, Death Anxiety Scale, and Health Anxiety Scale were collected through a specially designed structured questionnaire. First, participants were asked if they had a COVID-19 vaccine. The question "Are you considering getting vaccinated?" was asked to unvaccinated participants. Response options were "I accept the vaccine," "I refuse the vaccine," "I hesitate about the vaccine." Those who refused the vaccine and hesitated about it were asked about the factors affecting their attitude.

\section{Death Anxiety Scale}

The scale, developed by Templer in 1970, consists of 15 points. Its Turkish validity and reliability study was conducted in 2008 by Akça and Köse ${ }^{[6,7]}$. Correct items are rated as 1 and incorrect items as 0 . It is considered that values of 7 and higher are associated with anxiety of death.

\section{Short Health Anxiety Scale}

A self-report scale consisting of 18 items was developed by Salkovskis et al. in 2002, and its Turkish validity and reliability study was conducted in 2013 by Aydemir et al. ${ }^{[8,9]}$. Psychological variables associated with health anxiety are evaluated in the first 14 items of the scale. The feared consequences are evaluated in the last four items (if a participant has a severe illness). Cronbach alpha internal consistency coefficient was determined as 0.91 . The total scale score is calculated using the 0-3 scoring system. It has been reported that scores of 18 and above are associated with health anxiety ${ }^{[10,11]}$.

\section{Statistical analysis}

Statistical analysis was performed with IBM SPSS Statistics software, version 21.0. Results were expressed as mean \pm standard deviation or number (\%). Kolmogorov-Smirnov test was used to evaluate the normal distribution of quantitative data. Data with normal distribution were evaluated by Student's $t$ test and those without normal distribution were evaluated by Mann-Whitney U test. Chi-square test was used for categorical data. Kruskal-Wallis Test was used for comparison between the groups. Participants were divided into three groups according to their attitude towards the COVID-19 vaccine, vaccine acceptance, vaccine rejection, and vaccine hesitation. Multiple logistic regression analyses were used to determine factors associated with vaccine rejection and vaccine hesitancy. The associations between the risk factors and outcomes were presented as odds ratios (OR) and 95\% CI after adjusting for the confounders. $\mathrm{P}$ values less than 0.05 were considered significant for all tests.

\section{RESULTS}

\section{Demographic characteristics}

One thousand five hundred and forty-six people agreed to participate in the study. Most of the respondents were females (63.7\%) and under 60 (92.3\%). A total of 458 (29.6\%) of the participants had at least one chronic physical disorder, and 259 (16.8\%) had a mental illness. Demographic data were shown in the Table 1.

\section{Death and Health Anxiety}

Mean DAS score was $8.5 \pm 3.5$, and the HAI score was $14.4 \pm 7.4$. Higher Death Anxiety and Health Anxiety levels were observed in 70\% and $29.2 \%$ of the patients, respectively. 


\begin{tabular}{|c|c|}
\hline Characteristic & n (\%) \\
\hline \multicolumn{2}{|l|}{ Gender } \\
\hline Female & $985(63.7)$ \\
\hline Male & $561(36.3)$ \\
\hline \multicolumn{2}{|l|}{ Age } \\
\hline $60 \leq$ & $1427(92.3)$ \\
\hline $60>$ & 119 (7.7) \\
\hline \multicolumn{2}{|l|}{ Education level } \\
\hline High school and below & $158(10.2)$ \\
\hline University & $985(63.7)$ \\
\hline \multicolumn{2}{|l|}{ Place of residence } \\
\hline Urban & $251(16.2)$ \\
\hline Rural & $1295(83.8)$ \\
\hline \multicolumn{2}{|l|}{ Monthly income } \\
\hline$\leq$ Minimum wage* & $341(22.1)$ \\
\hline >Minimum wage & 1205 (77.9) \\
\hline \multicolumn{2}{|l|}{ Marital status } \\
\hline Single & $365(23.6)$ \\
\hline Married & $1181(76.4)$ \\
\hline $\begin{array}{l}\text { * Minimum wage }=2.825 \text { Turkis } \\
\text { participants. }\end{array}$ & L), n: number of \\
\hline
\end{tabular}

\section{Vaccine Attitudes}

Six hundred and ninety-nine (45.2\%) of the participants were vaccinated, and 550 (35.5\%) of them were expected to be vaccinated when their turn came. Vaccine hesitation among participants was 137 (8.9\%), while vaccine refusal was 140 (9\%).

Older age, higher level of education, healthcare occupation, lower concern over the vaccine was observed in the vaccine acceptance group compared to refusal and hesitancy groups $(\mathrm{p}<$ 0.05). The comparison of vaccine attitudes was shown in Table 2.

\section{Analysis of the Risk Factors Related to Vaccine Refusal and Hesitation}

Higher level of education (OR 0.53; 95\% CI= $0.30-0.94 ; p=0.03)$ and being a healthcare worker (OR 0.32; 95\% CI=0.19-0.53; $\mathrm{p}<0.01$ ) were found to decrease the risk of vaccine hesitancy. Negative concern about the vaccine was found to increase the risk of vaccine hesitancy (OR 13.4;
95\% CI= 7.11-25.7; $\mathrm{p}<0.01)$. Having higher Death Anxiety Score (OR 0.40; 95\% CI=0.27-0.61; $\mathrm{p}<0.01$ ) and being a healthcare worker (OR $0.28 ; 95 \% \mathrm{CI}=0.18-0.45 ; \mathrm{p}<0.01$ ) were found to decrease the risk of vaccine refusal. Negative concern over the vaccine (OR 6.72; 95\% CI= 4.16-10.85; $p<0.01$ ) was found to increase the risk of vaccine refusal. Tables 3 and 4 show the multivariable regression analyses of factors associated with vaccine refusal and hesitation.

\section{Reasons for Vaccine Refusal and Hesitation}

The most common reasons for vaccine refusal or vaccine hesitation were: concerns about the safety (respectively 52.9\%, 29.9\%) and effectiveness of vaccines $(47.9 \%, 29.9 \%)$, lack of reliable scientific data on COVID-19 vaccines $(70.7 \%$, $62 \%)$, thoughts on the vaccines that vaccines would not protect against the disease because the virus would mutate $(50 \%, 31.4 \%)$, and belief on the natural immunity that might be more protective instead of the vaccine $(52.1 \%, 27 \%)$. Participants who refused the vaccine or were hesitant to get it gave reasons for their decisions, as shown in Table 5.

\section{DISCUSSION}

To our knowledge, this is the first study investigating the relationship between vaccination attitude and death and disease anxiety at the time when vaccination services were initiated in Turkey. Vaccines are thought to be promising to eradicate COVID-19, spreading rapidly worldwide and causing millions of deaths. Given the disease's negative consequences, getting vaccinated as soon as possible seems like the right decision. It is emphasized that vaccines are critical in pandemics. Therefore, it is essential to determine the variables associated with negative attitudes towards vaccination in society.

In the early stages of the pandemic, when COVID-19 vaccination activities were not yet initiated, vaccine rejection and vaccine hesitation rates were observed at much higher rates than in our study ${ }^{[12,13]}$. Approximately half of the participants in the study of Fisher et al. reported vaccine hesitancy ${ }^{[14]}$. Paul et al. have reported that $23 \%$ of the respondents were hesitant about 
Table 2. Comparison of the participants divided into groups in terms of vaccine attitudes

\begin{tabular}{|c|c|c|c|c|c|}
\hline \multirow[t]{2}{*}{ Characteristic } & \multicolumn{3}{|c|}{ Vaccine Attitudes, n (\%) } & \multicolumn{2}{|c|}{ p } \\
\hline & $\begin{array}{l}\text { COVID-19 } \\
\text { Vaccine } \\
\text { Acceptance }\end{array}$ & $\begin{array}{l}\text { COVID-19 } \\
\text { Vaccine } \\
\text { Refusal }\end{array}$ & $\begin{array}{l}\text { COVID-19 } \\
\text { Vaccine } \\
\text { Hesitancy }\end{array}$ & $\begin{array}{l}\text { Acceptance } \\
\text { vs. Refusal }\end{array}$ & $\begin{array}{l}\text { Acceptance } \\
\text { vs. } \\
\text { Hesitancy }\end{array}$ \\
\hline Age groups & $\begin{array}{c}1159(81.2) \\
110(92.4)\end{array}$ & $\begin{array}{c}135(9.5) \\
5(4.2)\end{array}$ & $\begin{array}{c}133(9.3) \\
4(3.4)\end{array}$ & $0.037^{*}$ & $0.019^{*}$ \\
\hline $\begin{array}{r}\text { Female } \\
\text { Male }\end{array}$ & $\begin{array}{l}819(83.1) \\
450(80.2)\end{array}$ & $\begin{array}{c}80(8.1) \\
60(10.7)\end{array}$ & $\begin{array}{l}86(8.7) \\
51(9.1)\end{array}$ & 0.084 & 0.682 \\
\hline $\begin{array}{r}\text { High School and below } \\
\text { University }\end{array}$ & $\begin{array}{c}105(66.5) \\
1164(83.9)\end{array}$ & $\begin{array}{l}25(15.8) \\
115(8.3)\end{array}$ & $\begin{array}{l}28(17.7) \\
109(7.9)\end{array}$ & $<0.001^{*}$ & $<0.001^{*}$ \\
\hline Place of residence & $\begin{array}{c}1075(83.0) \\
194(77.3)\end{array}$ & $\begin{array}{l}111(8.6) \\
29(11.6)\end{array}$ & $\begin{array}{l}109(8.4) \\
28(11.2)\end{array}$ & 0.095 & 0.116 \\
\hline Working status & $\begin{array}{l}978(83.4) \\
291(78.0)\end{array}$ & $\begin{array}{c}104(8.9) \\
36(9.7)\end{array}$ & $\begin{array}{c}91(7.8) \\
46(12.3)\end{array}$ & 0.459 & $0.006^{*}$ \\
\hline Healthcare workers & $\begin{array}{l}622(92.0) \\
647(74.4)\end{array}$ & $\begin{array}{c}30(4.4) \\
110(12.6)\end{array}$ & $\begin{array}{c}24(3.6) \\
113(13.0)\end{array}$ & $<0.001^{*}$ & $<0.001^{*}$ \\
\hline Having dependents except for children & $\begin{array}{c}163(79.1) \\
1106(82.5)\end{array}$ & $\begin{array}{l}21(10.2) \\
119(8.9)\end{array}$ & $\begin{array}{l}22(10.7) \\
115(8.6)\end{array}$ & 0.473 & 0.290 \\
\hline $\begin{array}{r}\leq \text { Minimum wage }{ }^{* *} \\
>\text { Minimum wage }\end{array}$ & $\begin{array}{c}239(70.1) \\
1030(82.1)\end{array}$ & $\begin{array}{l}47(13.8) \\
93(7.7)\end{array}$ & $\begin{array}{l}55(16.1) \\
82(6.8)\end{array}$ & $<0.001^{*}$ & $<0.001^{*}$ \\
\hline Having children & $\begin{array}{l}876(82.4) \\
393(81.4)\end{array}$ & $\begin{array}{c}102(9.6) \\
38(7.9)\end{array}$ & $\begin{array}{l}85(8.0) \\
52(10.8)\end{array}$ & 0.351 & 0.095 \\
\hline $\begin{array}{r}\text { Single } \\
\text { Married }\end{array}$ & $\begin{array}{l}357(81.5) \\
912(82.3)\end{array}$ & $\begin{array}{c}37(8.4) \\
103(9.3)\end{array}$ & $\begin{array}{l}44(10.0) \\
93(8.4)\end{array}$ & 0.670 & 0.326 \\
\hline Having chronic disease & $\begin{array}{l}886(81.4) \\
383(83.6)\end{array}$ & $\begin{array}{l}98(9.0) \\
42(9.2)\end{array}$ & $\begin{array}{c}104(9.6) \\
33(7.2)\end{array}$ & 0.965 & 0.138 \\
\hline Having psychiatric disorder & $\begin{array}{c}216(83.4) \\
1053(81.8)\end{array}$ & $\begin{array}{c}22(8.5) \\
118(9.2)\end{array}$ & $\begin{array}{c}21(8.1) \\
116(9.0)\end{array}$ & 0.695 & 0.615 \\
\hline Had COVID-19 & $\begin{array}{c}180(72.6) \\
1089(83.9)\end{array}$ & $\begin{array}{l}50(20.2) \\
90(6.9)\end{array}$ & $\begin{array}{c}18(7.3) \\
119(9.2)\end{array}$ & $<0.001^{*}$ & 0.738 \\
\hline Contact with COVID-19 Patient & $\begin{array}{l}461(84.4) \\
808(80.8)\end{array}$ & $\begin{array}{l}51(9.3) \\
89(8.9)\end{array}$ & $\begin{array}{c}34(6.2) \\
103(10.3)\end{array}$ & 0.981 & $0.007^{*}$ \\
\hline $\begin{array}{r}\text { Living together with people in the risk group } \\
\text { Yes } \\
\text { No }\end{array}$ & $\begin{array}{l}591(84.9) \\
678(79.8)\end{array}$ & $\begin{array}{c}54(7.8) \\
86(10.1)\end{array}$ & $\begin{array}{c}51(7.3) \\
86(10.1)\end{array}$ & 0.071 & $0.037^{*}$ \\
\hline
\end{tabular}




\begin{tabular}{|c|c|c|c|c|c|}
\hline \multirow[t]{2}{*}{ Characteristic } & \multicolumn{3}{|c|}{ Vaccine Attitudes, n (\%) } & \multicolumn{2}{|c|}{$\mathbf{p}$} \\
\hline & $\begin{array}{l}\text { COVID-19 } \\
\text { Vaccine } \\
\text { Acceptance }\end{array}$ & $\begin{array}{l}\text { COVID-19 } \\
\text { Vaccine } \\
\text { Refusal }\end{array}$ & $\begin{array}{l}\text { COVID-19 } \\
\text { Vaccine } \\
\text { Hesitancy }\end{array}$ & $\begin{array}{l}\text { Acceptance } \\
\text { vs. Refusal }\end{array}$ & $\begin{array}{c}\text { Acceptance } \\
\text { vs. } \\
\text { Hesitancy }\end{array}$ \\
\hline The effect of COVID-19 on the financial condition & & & & 0.139 & 0.210 \\
\hline $\begin{array}{r}\text { Not affected/Slightly negatively affected } \\
\text { Moderately/Highly negatively affected }\end{array}$ & $\begin{array}{l}969(83.1) \\
300(78.9)\end{array}$ & $\begin{array}{c}99(8.5) \\
41(10.8)\end{array}$ & $\begin{array}{l}98(8.4) \\
39(10.3)\end{array}$ & & \\
\hline Worried about the COVID-19 vaccine & $\begin{array}{l}559(81.6) \\
710(82.5)\end{array}$ & $\begin{aligned} 115 & (16.8) \\
25 & (2.9)\end{aligned}$ & $\begin{array}{c}11(1.6) \\
126(14.6)\end{array}$ & $<0.001^{*}$ & $<0.001^{*}$ \\
\hline Death Anxiety Scale & $\begin{array}{l}373(80.6) \\
896(82.8)\end{array}$ & $\begin{array}{l}55(11.8) \\
85(7.8)\end{array}$ & $\begin{array}{c}35(7.6) \\
102(9.4)\end{array}$ & $0.016^{*}$ & 0.346 \\
\hline Health Anxiety Scale & $\begin{array}{l}893(81.6) \\
376(83.1)\end{array}$ & $\begin{array}{l}109(9.9) \\
31(6.9)\end{array}$ & $\begin{array}{l}92(8.4) \\
45(9.9)\end{array}$ & 0.064 & 0.435 \\
\hline
\end{tabular}

vaccination, and $14 \%$ did not want to be vaccinated $^{[15]}$. In the study of Malik et al., 67\% of the respondents have been found to accept the vaccine ${ }^{[16]}$. It was emphasized that the acceptance of vaccines at this level would not be sufficient to ensure herd immunity. Inversely, our study showed lower vaccine refusal rate compared to the literature. The observation that a good prognosis of the disease after vaccination and no important side effects of the vaccine may explain the lower level of vaccine refusal detected in the current study. The higher rate of negative attitude towards vaccination at the beginning of the pandemic may be due to no available reliable information about COVID-19 infection, prognosis, and treatment. Another reason for the less negative attitudes observed in our study may be the current initiation of vaccination activities and more information and experience about vaccines' effects on those already vaccinated.

Negative effects tend to occur in people's mental health during the COVID-19 pandemic, as similar public health events were observed in history ${ }^{[17]}$. Our study observed that $29.2 \%$ of the participants had health anxiety, and 70\% had death anxiety. The results of a study conducted with State Security Forces and Armed Forces employees in Spain are similar to our study's findings ${ }^{[18]}$. It has reported a total level of $69.2 \%$ on the death anxiety scale, with higher levels of fear of death of others (82.1\%) and fear of the process of dying of others (82.1\%). A study conducted in Turkey has found that those with comorbid psychiatric and chronic physical illnesses and women tend to have more health concerns in the pandemic ${ }^{[19]}$. The consequences of the pandemic, its duration, and uncertainties regarding the disease's clinical course, high transmission, and mortality rates may lead to a perception of threat and stress response initiation in humans. This can cause some people to focus on their bodily sensations, worry about their health, and death anxiety. For this reason, it is essential to include psychiatric services among the basic medical interventions in the management of the pandemic and to strengthen and support mental health.

Mental illnesses and stress are thought to affect vaccine intake ${ }^{[20]}$. In our study, we found that having a psychiatric illness is not a determinant of vaccine attitude. Although our study found that health anxiety was not a significant predictor of vaccination attitude, we observed that those who rejected the COVID-19 vaccine tended to have lower death anxiety than those who accepted it. A certain level of anxiety can force people to take action against the virus's transmission or spread. A low level of death anxiety may negatively affect people's health by not adapting to immunization services. 
Table 3. Multivariate predictors of responding "COVID-19 vaccine hesitancy" regarding intent to be vaccinated

\begin{tabular}{|c|c|c|}
\hline Characteristic & Multivariate Analysis & \\
\hline & OR $(95 \% \mathrm{Cl})$ & $\mathrm{p}$ \\
\hline \multicolumn{3}{|l|}{ Age groups } \\
\hline$\leq 60$ & Reference & 0.066 \\
\hline$>60$ & $0.357(0.11-1.07)$ & \\
\hline \multicolumn{3}{|l|}{ Education level } \\
\hline High School and below & Reference & $0.033^{*}$ \\
\hline University & $0.534(0.30-0.94)$ & \\
\hline \multicolumn{3}{|l|}{ Working status } \\
\hline No & Reference & 0.716 \\
\hline Yes & $1.106(0.64-1.89)$ & \\
\hline \multicolumn{3}{|l|}{ Healthcare workers } \\
\hline No & Reference & $<0.001^{*}$ \\
\hline Yes & $0.320(0.19-0.53)$ & \\
\hline \multicolumn{3}{|l|}{ Monthly income } \\
\hline$\leq$ Minimum wage & Reference & 0.060 \\
\hline >Minimum wage & $0.604(0.35-1.02)$ & \\
\hline \multicolumn{3}{|c|}{ Contact with COVID-19 Patient } \\
\hline No & Reference & 0.475 \\
\hline Yes & $0.847(0.53-1.33)$ & \\
\hline \multicolumn{3}{|c|}{ Living together with people in the risk group } \\
\hline No & Reference & 0.268 \\
\hline Yes & $0.796(0.53-1.19)$ & \\
\hline \multicolumn{3}{|c|}{ Worried about the COVID-19 vaccine } \\
\hline No & Reference & $<0.001^{*}$ \\
\hline Yes & $13.4(7.11-25.27)$ & \\
\hline
\end{tabular}

It has been reported that having a chronic disease may affect the thoughts, attitudes, behaviors, and vaccine willingness towards $\mathrm{CO}$ VID-19 ${ }^{[21]}$. Interestingly, we found that having a chronic disease was not a determining factor in vaccine attitudes. This situation may be related to the fact that SARS-CoV-2 could cause serious negative consequences not only in patients with chronic diseases but also in healthy people. Encouraging those with chronic physical illnesses in the risk group to accept the COVID-19 vaccine may reduce morbidity and mortality rates.

One of the essential determinants in using preventive health services is the level of educa- tion. According to the literature, low education level was a predictor for those hesitant to be vaccinated against COVID-19 in our study. It is very important to provide health education and information about COVID-19 and its vaccines, including people with low education levels, in controlling the pandemic.

Another remarkable finding was that the rate of vaccine rejection and hesitation among healthcare workers was significantly lower than in non-healthcare workers. We found that non-healthcare occupation was a predictor of both vaccine hesitancy and vaccine rejection. The study of Dror et al. has also found that vaccination acceptan- 
Table 4. Multivariate predictors of responding "COVID-19 vaccine refusal" regarding intent to be vaccinated

\begin{tabular}{|c|c|c|}
\hline Characteristic & Multivariate Analysis & \\
\hline & OR $(95 \% \mathrm{Cl})$ & $P$ \\
\hline \multicolumn{3}{|l|}{ Age groups } \\
\hline$\leq 60$ & Reference & 0.064 \\
\hline$>60$ & $0.402(0.15-1.05)$ & \\
\hline \multicolumn{3}{|l|}{ Education level } \\
\hline High School and below & Reference & 0.097 \\
\hline University & $0.610(0.34-1.09)$ & \\
\hline \multicolumn{3}{|l|}{ Healthcare workers } \\
\hline No & Reference & $<0.001^{*}$ \\
\hline Yes & $0.289(0.18-0.45)$ & \\
\hline \multicolumn{3}{|l|}{ Monthly income } \\
\hline$\leq$ Minimum wage & Reference & 0.301 \\
\hline >Minimum wage & $0.783(0.49-1.24)$ & \\
\hline \multicolumn{3}{|l|}{ Had COVID-19 } \\
\hline No & Reference & $<0.001^{*}$ \\
\hline Yes & $4.320(2.82-6.61)$ & \\
\hline \multicolumn{3}{|c|}{ Worried about the COVID-19 vaccine } \\
\hline No & Reference & $<0.001^{*}$ \\
\hline Yes & $6.721(4.16-10.85)$ & \\
\hline \multicolumn{3}{|l|}{ Death Anxiety Scale } \\
\hline$<7$ & Reference & $<0.001^{*}$ \\
\hline$\geq 7$ & $0.407(0.27-0.61)$ & \\
\hline
\end{tabular}

${ }^{*} \mathrm{p}<.05$, OR: Odds Ratio, $95 \% \mathrm{Cl}: 95 \%$ confidence interval.

ce rates among healthcare professionals working in the COVID-19 unit were higher than those working in other units ${ }^{[22]}$. One of the critical reasons behind health professionals' positive attitudes towards vaccination may be their motivation to take precautions against the possibility of the virus being transmitted to them and infecting others.

We also found that history of COVID-19 infection was an important determinant of vaccine rejection. Beliefs that the innate immunity gained after the infection will protect from re-infection may be underlying thoughts of vaccine rejection. It was observed that antibodies begin to form within 2-3 weeks following the SARS-CoV-2 infection, but antibody levels decrease within mont$\mathrm{hs}^{[23]}$. For this reason, it is recommended that people in high-risk groups for transmission of the virus should be vaccinated against the possibility of re-infection ${ }^{[15]}$

We found that the strongest predictor of negative attitudes towards vaccination is concern over COVID-19 vaccines. Similar to data from many studies, our study found that concerns about vaccines' safety and efficacy are the most common reasons behind negative attitudes towards the $\mathrm{CO}$ VID-19 vaccine ${ }^{[14]}$. The rapid spread of new information about the SARS-CoV-2 virus and vaccine - true and false - may have affected public beliefs and trust in medicine ${ }^{[24]}$. The shorter development stages of COVID-19 vaccines compared to other vaccines may exaggerate previous biases. The widely publicized debates about safety and efficacy 
Table 5. Reasons participants provided for "COVID-19 vaccine refusal" and "COVID-19 vaccine hesitancy" regarding intent to be vaccinated

\begin{tabular}{|c|c|c|}
\hline $\begin{array}{l}\text { Reasons and affirmative responses with the per- } \\
\text { centage }\end{array}$ & $\begin{array}{l}\text { COVID-19 Vaccine Refusal } \\
\text { n (\%) }\end{array}$ & $\begin{array}{l}\text { COVID-19 Vaccine Hesitancy } \\
\text { n (\%) }\end{array}$ \\
\hline Society must be vaccinated to control the pandemic. & $33(23.6)$ & $65(47.4)$ \\
\hline The vaccines do not have enough effectiveness. & $67(47.9)$ & $41(29.9)$ \\
\hline The vaccines cause the transmission of the virus. & $15(10.7)$ & $11(8)$ \\
\hline The vaccines cause serious side effects. & $63(45)$ & $27(19.7)$ \\
\hline $\begin{array}{l}\text { The vaccines are unreliable as they are quickly devel- } \\
\text { oped. }\end{array}$ & $74(52.9)$ & $41(29.9)$ \\
\hline The vaccines are biological weapons. & $48(34.3)$ & $29(21.2)$ \\
\hline $\begin{array}{l}\text { There is not enough scientific data about the vac- } \\
\text { cines. }\end{array}$ & $99(70.7)$ & $85(62.0)$ \\
\hline The vaccines harm pregnant women. & $51(36.4)$ & $39(28.5)$ \\
\hline The vaccines harm children. & $56(40)$ & $21(22.6)$ \\
\hline $\begin{array}{l}\text { The vaccines are unnecessary as COVID-19 is a dis- } \\
\text { ease with mild complaints. }\end{array}$ & $38(27.2)$ & $6(4.4)$ \\
\hline $\begin{array}{l}\text { Natural immunity to COVID-19 is a better way than } \\
\text { vaccination. }\end{array}$ & $73(52.1)$ & $27(27.0)$ \\
\hline $\begin{array}{l}\text { The vaccines will not protect from the disease as the } \\
\text { virus will mutate. }\end{array}$ & $70(50)$ & $43(31.4)$ \\
\hline $\begin{array}{l}\text { Generally, all vaccines are useless, so the COVID-19 } \\
\text { vaccines are unnecessary. }\end{array}$ & $22(15.7)$ & $3(2.2)$ \\
\hline
\end{tabular}

concerns and the anti-vaccine rhetoric on social media may have caused this negative attitude.

Our study has a few limitations regarding its design and data collection method. Due to the study's cross-sectional nature, it was not possible to reveal a cause-effect relationship between vaccine attitudes and psychosocial variables. Although some themes influencing vaccination attitudes have emerged from our study's cross-sectional analysis, longitudinal cohort-based approaches that include more cultural and geographic specificity to evaluate individual attitude-behavior relationships would better identify attitudes towards the vaccines. Using an online web-based survey may have caused sample selection bias. Therefore, our results might not represent the general society. Despite these limitations, our study's data, which evaluates attitudes towards vaccination after successful vaccine trials are approved and rolled out, are very important.

\section{CONCLUSION}

Despite these limitations, our study suggested that vaccine hesitancy was related to lower education level and non-healthcare occupation. Vaccine refusal was related to history of COVID-19 infection, non-healthcare occupation, lower level of death anxiety scale. The concern on the vaccine was the most significant risk factor both for vaccine hesitancy and refusal. An essential pillar of vaccination campaigns should provide accurate vaccination information to the public, taking into account negative attitudes towards vaccines.

\section{ETHICS COMMITTEE APPROVAL}

This research was approved by Süleyman Demirel University Faculty of Medicine Clinical Research Ethics Committee (Date: 08/01/2021, Number: 15). 


\section{CONFLICT of INTEREST}

None of the authors had conflict of interest.

\section{AUTHORSHIP CONTRIBUTIONS}

Concept and Design: OU், GÖU்

Data Collection or Processing: GÖU், OU், SEÖ

Analysis/Interpretation: OU், GÖU், SEÖ

Literature Search: All of authors

Writing: OU்

Final Approval: All of authors

\section{REFERENCES}

1. World Health Organization (WHO). Coronavirus (COVID-19) Dashboard [cited 2021 30.06.2021]. Available from: https://covid19.who.int/.

2. Cummings MJ, Baldwin MR, Abrams $D$, Jacobson $S D$ Meyer BJ, Balough EM, et al. Epidemiology, clinical course, and outcomes of critically ill adults with COVID-19 in New York City: a prospective cohort study. Lancet 2020;395(10239):1 163-70.

3. T.C. Sağlık Bakanlığı COVID-19 Aşısı Bilgilendirme Platformu. Accessed date: 30.06.2021. Available from: https:// covid19asi.saglik.gov.tr/.

4. Guzman-Holst A, DeAntonio R, Prado-Cohrs D, Juliao P. Barriers to vaccination in Latin America: A systematic literature review. Vaccine 2020;38(3):470-81.

5. Salari $N$, Hosseinian-Far $A$, Jalali $R$, Vaisi-Raygani $A, R a-$ soulpoor S, Mohammadi $M$, et al. Prevalence of stress, anxiety, depression among the general population during the COVID-19 pandemic: a systematic review and meta-analysis. Global Health 2020;16(1):57.

6. Akca $F$, Kose A. Adaptation of death anxiety scale (DAS): validity and reliability studies. Journal of Clinical Psychiatry 2008;11:7-16.

7. Templer DI. The construction and validation of a Death Anxiety Scale. J Gen Psychol. 1970;82(2d Half):165-77.

8. Aydemir O, Kirpinar I, Sati T, Uykur B, Cengisiz C. Reliability and Validity of the Turkish Version of the Health Anxiety Inventory. Noro Psikiyatr Ars 2013;50(4):325-31.

9. Salkovskis PM, Rimes KA, Warwick HM, Clark DM. The Health Anxiety Inventory: development and validation of scales for the measurement of health anxiety and hypochondriasis. Psychol Med 2002;32(5):843-53.

10. Alberts NM, Hadjistavropoulos HD, Jones SL, Sharpe D. The Short Health Anxiety Inventory: a systematic review and meta-analysis. J Anxiety Disord 2013;27(1):68-78.

11. Rode S, Salkovskis $P$, Dowd H, Hanna M. Health anxiety levels in chronic pain clinic attenders. I Psychosom Res 2006;60(2):155-61.

12. Alabdulla M, Reagu SM, Al-Khal A, Elzain M, Jones RM. COVID-19 vaccine hesitancy and attitudes in Qatar: A national cross-sectional survey of a migrant-majority population. Influenza Other Respir Viruses 2021 May;15(3):361-70.
13. Salali GD, Uysal MS. COVID-19 vaccine hesitancy is associated with beliefs on the origin of the novel coronavirus in the UK and Turkey. Psychol Med 2020:1-3.

14. Fisher KA, Bloomstone SJ, Walder J, Crawford S, Fouayzi H, Mazor KM. Attitudes Toward a Potential SARSCoV-2 Vaccine: A Survey of U.S. Adults. Ann Intern Med 2020;173(12):964-73.

15. Paul E, Steptoe A, Fancourt D. Attitudes towards vaccines and intention to vaccinate against COVID-19: Implications for public health communications. The Lancet Regional Health-Europe 2021;1:100012.

16. Malik AA, McFadden SM, Elharake J, Omer SB. Determinants of COVID-19 vaccine acceptance in the US. EC linical Medicine. 2020;26:100495.

17. Morgul E, Bener A, Atak M, Akyel S, Aktas S, Bhugra D, et al. COVID-19 pandemic and psychological fatigue in Turkey. Int J Soc Psychiatry 2020:20764020941889.

18. Lazaro-Perez C, Martinez-Lopez JA, Gomez-Galan J, Fernandez-Martinez MDM. COVID-19 Pandemic and Death Anxiety in Security Forces in Spain. Int I Environ Res Public Health 2020;17(21).

19. Ozdin S, Bayrak Ozdin S. Levels and predictors of anxiety, depression and health anxiety during COVID-19 pandemic in Turkish society: The importance of gender. Int J Soc Psychiatry 2020;66(5):504-11.

20. The Lancet Infectious Diseases (editorial). The intersection of COVID-19 and mental health. Lancet Infect Dis 2020;20(11):1217.

21. Wolf MS, Serper M, Opsasnick L, O'Conor RM, Curtis L, Benavente JY, et al. Awareness, Attitudes, and Actions Related to COVID-19 Among Adults With Chronic Conditions at the Onset of the U.S. Outbreak: A Cross-sectional Survey. Ann Intern Med 2020;173(2):100-9.

22. Dror AA, Eisenbach N, Taiber S, Morozov NG, Mizrachi M, Zigron A, et al. Vaccine hesitancy: the next challenge in the fight against COVID-19. Eur J Epidemiol 2020;35(8):7759.

23. Liu A, Wang $W$, Zhao X, Zhou X, Yang $D$, Lu $M$, et al. Disappearance of antibodies to SARS-CoV-2 in a -COVID-19 patient after recovery. Clin Microbiol Infect 2020;26(12):1703-5.

24. Puri $N$, Coomes EA, Haghbayan $H$, Gunaratne $K$. Social media and vaccine hesitancy: new updates for the era of COVID-19 and globalized infectious diseases. Hum Vaccin Immunother 2020;16(11):2586-93.

\section{Address for Correspondence/Yazıșma Adresi}

Dr. Onur ÜNAL

Süleyman Demirel Üniversitesi Tıp Fakültesi,

İnfeksiyon Hastalıkları ve

Klinik Mikrobiyoloji Anabilim Dal

Isparta-Türkiye

E-posta: onurunal_84@hotmail.com 